\title{
THE PROTECTION OF THE ACCUSED IN INTERNATIONAL CRIMINAL LAW ACCORDING TO THE HUMAN RIGHTS LAW STANDARD ${ }^{1}$
}

\author{
KAROLINA KREMENS*
}

\section{INTRODUCTION}

The protection of the accused remains invariably in the interest of all civilized systems of law. All legal systems provide certain standards for the rights of the accused. Those rights guarantee that if criminal proceedings are held no harm will be done to the alleged offender and his right to a fair trial will be assured. Those ideas, developed in the human rights law, have been adopted both on the national and international level.

This paper tries to give an answer to the question of whether rules protecting the accused in international criminal proceedings meet the human rights law standard provided by international declarations and covenants, and if the adoption of those standards on the international level prescribed in the law of international criminal tribunals and courts has been successful. Meaning, if the proceedings before the International Criminal Tribunal for Former Yugoslavia (ICTY), International Criminal Tribunal for Rwanda (ICTR) and International Criminal Court (ICC) meet the standards provided by international human rights law.

This paper's aim is to describe and compare the rights of the accused during the trial assured by international human rights law and those presented in the international criminal law. ${ }^{2}$ As a legal basis for discussion on those issues,

DOI: $10.2478 /$ wrlae-2013-0026

* PhD; LLM; University of Wroclaw, Department of Forensic Sciences; karolina.kremens@gazeta.pl

${ }^{1}$ The author wishes to thank Professor John H. Curie (University of Ottawa) for his help and supervision.

2 The analysis of the rights of the accused in the law of the International Criminal Tribunal for the former Yugoslavia and International Criminal Tribunal for Rwanda is the subject of one of the chapters in my book entitled Dowody osobowe $w$ międzynarodowym postepowaniu karnym (TNOiK 2010) 179-207. See also on the analysis of the rights of the accused in the International Criminal Court Michał Płachta, Międzynarodowy Trybunat Karny, vol. 1 (Zakamycze 2004) and Michał Królikowski, Paweł Wiliński, Jacek Izydorczyk, Podstawy prawa karnego międzynarodowego (Wolters Kluwer Polska 2008). 
from the perspective of international human rights law the comparison will be based on the Universal Declaration of Human Rights ${ }^{3}$, and in particular the International Covenant on Civil and Political Rights ${ }^{4}$ with occasional reference to other international instruments ${ }^{5}$, and on the other hand international criminal proceedings regulations in ICTY, ICTR and ICC Statutes ${ }^{6}$ as well as their Rules of Procedure and Evidence ${ }^{7}$. As necessary, reference will be made to the law of the Nuremberg Tribunal ${ }^{8}$ and Tokyo Tribunal $^{9}$ and other international human rights law sources to point out differences and progress that was made in international criminal law regarding rights of the accused by the implementation of the international human rights law standards in 1948 and 1966.

The paper is divided in to two parts. The first part contains an introductory chapter presenting an overview of the major issues raised within this paper. This chapter will discuss the framework of international human rights law with regard to the protection of the accused in conventions and other sources of international law. Furthermore the notion of international criminal law will be discussed. It will conclude with an explanation of the notion of the accused in criminal law and international criminal law which is crucial to understanding the complicated issues surrounding protection of the accused during distinct stages of proceedings.

The second part is devoted to a presentation of particular rights guaranteed for the protection of the accused. Those issues are discussed by way of an analysis of the appropriate rights of the accused provided by the UDHR

${ }^{3}$ Universal Declaration of Human Rights, UNGA Res 217A (III) (10 December 1948) UN Doc A/810 (UDHR).

${ }^{4}$ International Covenant on Civil and Political Rights (adopted on 16 December 1966, entered into force on 23 March 1976) 999 UNTS 171 (ICCPR).

5 Convention for the Protection of Human Rights and Fundamental Freedoms (European Convention on Human Rights, as amended) (adopted on 4 November 1950, entered into force on 3 September 1953) (ECHR) and American Convention on Human Rights (adopted on 22 November 1969, entered into force 18 July 1978) (AmCHR).

${ }^{6}$ Statute of the International Criminal Tribunal for the Former Yugoslavia, UNSC Res 827 (adopted on 25 May 1993, last amended on 7 July 2009) (ICTY Statute); Statute of the International Criminal Tribunal for Rwanda, UNSC Res. 955 (adopted 8 November 1994, last amended on 16 December 2009) (ICTR Statute); 'Final Act of the UN Diplomatic Conference of Plenipotentiaries on the Establishment of an International Criminal Court' (17 July 1998) UN Doc A/CONF.183/10 (Rome Statute).

${ }^{7}$ Rules of Procedure and Evidence of the International Criminal Tribunal for the Former Yugoslavia, IT/32/Rev.38 (adopted on 11 February 1994, last amended on 8 December 2010) (ICTY RPE); Rules of Procedure and Evidence of the International Criminal Tribunal for Rwanda, ITR/3/Rev.15 (adopted on 29 June 1995, last amended on 1 October 2009) (ICTR RPE); Rules of Procedure and Evidence. Addendum to the Report of the Preparatory Commission for the International Criminal Court, PCNICC/2000/INF/3/Add.1 (adopted on 12 July 2000) (ICC RPE).

${ }^{8}$ International Military Tribunal established by France, the United Kingdom, the Soviet Union and the United States pursuant to Agreement for the Prosecution and Punishment of the Major War Criminals of the European Axis (so-called London Agreement) 82 UNTS 279 (8 August 1945).

${ }^{9}$ International Military Tribunal for the Far East established on 19 January 1946 by the Supreme Commander of the Allied Powers, General Douglas McArthur; US Dep't of State Pub. No. 2675, TIAS No. 1589. 
(Articles 10 and 11) and ICCPR (Article 14) and then comparing those with corresponding guarantees provided in the law of international criminal tribunals and courts. The chapter is structured based on the provisions of Article 14 of the ICCPR. Therefore, the rights of the accused will be presented as follows: 1 . the right to a fair trial; 2 . the presumption of innocence; 3 . the right to be informed of charges against him or her; 4 . the right to an expeditious trial and to have time for preparation of a defence; 5 . the right to counsel; 6 . the prohibition of trials in absentia; 7. the right to examine witnesses or have them examined; 8 . the right to an interpreter; 9. the right to remain silent.

The paper concludes with closing remarks on the protection of the rights of the accused in international criminal proceedings. After an in-depth analysis on the level of protection of the accused within both branches of international law, I argue that the safeguards provided in the law of international courts and tribunals set out higher standard than those prescribed in the ICCPR and UDHR.

\section{GENERAL ISSUES}

\section{A. The framework of international human rights law}

International human rights law is a post-Second World War phenomenon that arose from the necessity of ensuring that the tragedies and misfortunes of that period would never happen again, or would at least be limited with respect to the group of standard rules referred to as human rights. This branch of law is hard to define and scholars are not necessarily very eager to give a straightforward answer as to what exactly international human rights law means. Some may say that it is a mechanism in which 'every individual has certain inalienable and legally enforceable rights protecting him or her against state interference and the abuse of power by governments'. ${ }^{10}$ In other words '[i]t asserts that every human being, in every society, is entitled to have basic autonomy and freedoms respected and basic needs satisfied'. ${ }^{11}$

To achieve all of its aims, international human rights law consists of a group of treaties, conventions and declarations which provide the international community with guidelines and obligations regarding rights that are indispensable and need to be protected on both the national and international levels. It is impossible to understand the human rights movement without recognizing the role of international organizations, among which the United Nations has played a key role since its birth in $1945 .^{12}$ This organization adopted

\footnotetext{
${ }^{10}$ Peter Malanczuk, Akehurst's Modern Introduction to International Law (7th edn, Routledge 1997) 209.

${ }^{11}$ Louis Henkin, 'Introduction' in Louis Henkin (ed), The International Bill of Rights. The Covenant on Civil and Political Rights (Columbia University Press 1981) 1.

12 See more in Henry J Steiner and Philip Alston, International Human Rights in Context. Law, Politics and Morals (2nd edn, OUP 2000) 137. See also William A Schabas, International Human Rights Law and the Canadian Charter (2nd edn, Carswell Thomson Professional Publishing 1996) 56.
} 
such important sources of international law as the Charter of the United Nations ${ }^{13}$ and UDHR, whose creation spawned the adoption of countless treaties covering issues concerning human rights.

Nevertheless, not every convention providing norms on human rights is addressed to everyone. Some of the treaties refer to particular groups of people. Good examples of those are the Convention on the Rights of the Child ${ }^{14}$ which is addressed solely to the under-aged and protects only their rights, as well as the Convention on the Elimination of All Forms of Discrimination against Women ${ }^{15}$ which concerns only the rights of women.

This paper deals with a special group of rights that are addressed to every human being, however only when facing the extraordinary situation of being the object of criminal proceedings. During this particular time the individual is protected by rules that guarantee him such basic rights as the presumption of innocence, prohibition of arbitrary arrest and detention as well as equality before impartial and independent courts and tribunals.

I must agree with Haji N. A. Noor Muhammad, who argued that '[a] significant development in human rights since the Second World War was the adoption of the fundamental concept of $<<$ due process of law $>>$ in the Universal Declaration of Human Rights and the elaboration of this concept into building legal obligations on the states parties to the International Covenant on Civil and Political Rights'. ${ }^{16}$ We shall see that the fair trial standard has improved since the adoption of the ICCPR.

\section{B. International Criminal Law}

Similarly, there is no general agreement between scholars as to the definition of international criminal law. In the words of one expert in this branch of law, Kriangsak Kittichaisaree, international criminal law is 'law that governs international crimes; is where the penal aspects of international law, including that body of law protecting victims of armed conflict known as international humanitarian law, and the international aspects of national criminal law, converge'. ${ }^{17}$ On the other hand, Antonio Cassese believes that '[i]nternational criminal law is a body of international rules designed both to proscribe international crimes and to impose upon States the obligation to prosecute and punish at least some of those crimes'. ${ }^{18}$

Nevertheless, some features of international criminal law are widely recognized in the literature. First of all, it is settled that it is a mixture of common

${ }^{13}$ Charter of the United Nations, 59 Stat. 1031 (adopted on 26 June 1945 entered into force on 24 October 1945) TS 993.

${ }^{14}$ Convention on the Rights of the Child, 1577 UNTS 3 (adopted on 20 November 1989 entered into force 2 September 1990) 28 ILM 1456.

${ }^{15}$ Convention on the Elimination of All Forms of Discrimination against Women, 1249 UNTS 13 (adopted on 18 December 1979, entered into force 3 September 1981) 19 ILM 33.

${ }^{16}$ Haji NA Noor Muhammad, 'Due Process of Law for Persons Accused of Crime' in Louis Henkin (ed), The International Bill of Rights. The Covenant on Civil and Political Rights (Columbia University Press 1981) 139.

${ }^{17}$ Kriangsak Kittichaisaree, International Criminal Law (OUP 2001) 3.

${ }^{18}$ Antonio Cassese, International Criminal Law (OUP 2003) 15. 
and civil law systems ${ }^{19}$, especially from the procedural point of view. Secondly, international criminal law is seen as an extremely complicated branch of law combining principles of criminal and international law incorporated into human rights and humanitarian law. The influence of international law on international criminal law is particularly visible in the area of substantive law; war crimes are believed to be derived from humanitarian law while crimes against humanity originate from human rights law. ${ }^{20}$

It is agreed that the concept of international criminal law was born in 1945 when tribunals of historic importance were established for the purpose of prosecuting and punishing the perpetrators of international crimes committed during the Second World War. At the present time the international community can follow the proceedings carried out before the two ad hoc tribunals currently functioning, i.e. ICTY and ICTR, as well as the permanent ICC. Undoubtedly these three bodies are responsible for the current shape of the protection of the accused on the international level, which has had a remarkable impact on national laws. They definitely provide higher standards for the protection of the rights of the accused and fair trial principles than those observed in the law of the historical tribunals. $^{21}$ This is partially due to the fact that in between the establishment of the historical and modern tribunals the UDHR and ICCPR were adopted.

\section{Notion of the accused in criminal law}

One of the main issues in discussions about the differences between common and civil law systems is the distinction in understanding the notions of particular institutions. Among others, civil and common law systems differ in the notion of an accused and a suspect. In the continental law system an individual usually becomes a suspect when charges against him or her are filed. Then, with the filing of an indictment by the prosecutor and its acceptance by the court, the suspect becomes the accused. In the common law system the borderline remains at the moment in which notification of the charges is given. Until that time the

${ }^{19}$ Common law or 'adversarial', 'accusatorial' system is the one that is applied in the AngloAmerican world (England, United States, Canada, Australia, some African and Asian countries) while the civil law system, sometimes referred to as the continental or 'inquisitorial' one is present in continental Europe, some African and Asian countries and most of South America. The main difference between those two systems generally can be captured in the approach to the establishment of the truth during criminal proceedings. The former system believes that the best way to discover the truth is through an adversarial trial where two equal parties present their evidence before an impartial judge, while the latter argues that the truth should be established both during the preliminary investigation and trial proceedings, and both prosecutor and judge are obliged to seek the truth. See Abraham S Goldstein, 'Reflections on Two Models: Inquisitorial Themes in American Criminal Procedure' (1974) 26 Stanford Law Review 1009; Mireille Delmas-Marty and JR Spencer (ed), European Criminal Procedure (Cambridge University Press 2002); Daryl A Mundis, "From "Common Law" Towards "Civil Law" The Evolution of the ICTY Rules of Procedure and Evidence’ (2001) 14 Leiden J Intl L 368; Peter Carmichael Keen, 'Tempered Adversariality: The Judicial Role and Trial Theory in the International Criminal Tribunals' (2004) 17 Leiden J Intl L 767.

${ }^{20}$ Cassese (n 18) 64.

${ }^{21}$ Karin N Calvo-Goller, The Trial Proceedings of the International Criminal Court. ICTY and ICTR precedents (Martinus Nijhoff Publishers 2006) 17. 
person can be called a suspect, after - an accused. However, it must be noted that the common law system is far less precise on this issue, not getting too involved in theoretical discussions on the exact moments when one becomes a suspect or an accused.

Statutes of both ad hoc tribunals differentiate between the notion of suspect (Article 18 of the ICTY Statute and Article 17 of the ICTR Statute) and the notion of accused (Article 21 of the ICTY Statute and Article 20 of the ICTR Statute). However, the moment of the shift in status from suspect to accused is provided in Rule 47 (H) (ii) ICTY/R Rules of Procedure and Evidence. ${ }^{22}$ The Rule provides that ' $[\mathrm{u}]$ pon confirmation of any or all count in the indictment (...) the suspect shall have the status of an accused'. ${ }^{23}$

The Rome Statute mentions the term 'accused' in Article $61^{24}$ referring to the amendment to the confirmation of charges. On the other hand, it neither defines the notion of the term nor provides the moment in which a person becomes an accused. Therefore, it can be presumed that in the law of the ICC the common law approach to the accused has been adopted since, even before filing an indictment with the court, somewhere around the moment of confirmation of charges, a person may become the accused. The ICC Rules of Procedure and Evidence $^{25}$ upholds this approach providing in Rule 76 (3) that the accused may take an active part in the pre-trial disclosure of evidence. Interestingly, neither the Rome Statute nor ICC RPE refer to the term 'suspect' in the text of the treaty. Instead, several articles of the Statute introduce the notion of the "person during investigation'. ${ }^{26}$

However, it is necessary to identify in which moment the suspect becomes the accused simply because certain rights are provided only for him or her and not the suspect. Therefore, the accused may expect a higher level of protection than that when he was 'only' a suspect. The differences in the protection of suspects and accused are tremendous. The lack of explicit provisions with regard to this matter in the law of international courts and tribunals leaves too much space for interpretation and may result in uneven treatment of accused participating in criminal trials.

22 Rules of Procedure and Evidence of the International Criminal Tribunal for the Former Yugoslavia, IT/32/Rev.38 (adopted on 11 February 1994, last amended on 8 December 2010) (ICTY RPE); Rules of Procedure and Evidence of the International Criminal Tribunal for Rwanda, ITR/3/Rev.15 (adopted on 5 July 1995, last amended on 1 October 2009) (ICTR RPE). ${ }^{23}$ Moreover, RPE of both tribunals confirm in Rule 2 (A) the definition of accused, providing that this is '[a] person against whom one or more counts in an indictment have been confirmed in accordance with Rule 47'. The RPE also define the notion of suspect, providing that this is '[a] person concerning whom the Prosecutor possesses reliable information which tends to show that the person may have committed a crime over which the Tribunal has jurisdiction'.

${ }^{24}$ Article 61 (9) in principio of the Rome Statute provides that '[a]fter the charges are confirmed and before the trial has begun, the Prosecutor may, with the permission of the Pre-Trial Chamber and after notice to the accused, amend the charges'.

${ }^{25}$ Rules of Procedure and Evidence. Addendum to the Report of the Preparatory Commission for the International Criminal Court, PCNICC/2000/INF/3/Add.1 (adopted on 12 July 2000) (ICC RPE).

${ }^{26}$ See e.g. Article 55 of the Rome Statute providing rights of persons during an investigation. 


\section{THE RIGHTS OF THE ACCUSED}

\section{A. The right to a fair trial}

As Judge Richard May and Marieke Wierda argue, 'the object and purpose of the modern tribunals is to contribute to the restoration and maintenance of peace and security in the former Yugoslavia and Rwanda. This is to be achieved through conducting fair and expeditious trials'. ${ }^{27}$ But what in fact does it mean that a trial needs to be fair? This expression, often used within the provisions of human rights law, consists of distinguishable elements.

Primarily the right to a fair trial was prescribed in the provisions of Article 10 UDHR stating that '[e]veryone is entitled in full equality to a fair and public hearing by an independent and impartial tribunal, in the determination of his rights and obligations and of any criminal charge against him'. Furthermore, the scope was broadened by Article 14 (1) ICCPR stating:

'All persons shall be equal before the courts and tribunals. In the determination of any criminal charge against him, or of his rights and obligations in a suit at law, everyone shall be entitled to a fair and public hearing by a competent, independent and impartial tribunal established by law. The press and the public may be excluded from all or part of a trial for reasons of morals, public order (ordre public) or national security in a democratic society, or when the interest of the private lives of the parties so requires, or to the extent strictly necessary in the opinion of the court in special circumstances where publicity would prejudice the interests of justice; but any judgment rendered in a criminal case or in a suit at law shall be made public except where the interest of juvenile persons otherwise requires or the proceedings concern matrimonial disputes or the guardianship of children'.

In spite of the fact that the provisions of Article 14 provide a list of certain rights, there is no agreement on what concepts are in fact incorporated in this broad notion. For example, according to Antonio Cassese they are equality of arms, publicity of proceedings and expeditiousness of proceedings ${ }^{28}$, even though the right to an expeditious trial is provided by Article 14 (3) (c) ${ }^{29}$. Haji N. A. Noor Muhammad believes that elements of a fair trial are the equality of parties, a competent, independent and impartial tribunal established by law and a public trial. ${ }^{30}$ Moreover, the case law of international criminal tribunals seems to agree that impartiality and independence of the tribunal assists in ensuring the right to a fair trial, as it was held in the Furundzija case: '[t]he fundamental human right of an accused to be tried before an independent and impartial tribunal

${ }^{27}$ Richard May and Marieke Wierda, International Criminal Evidence (Transnational Publishers 2002) 260.

${ }^{28}$ Cassese (n 18) 395.

${ }^{29}$ In the determination of any criminal charges against him, everyone shall be entitled (...) to be tried without undue delay.

${ }^{30}$ Haji NA Noor Muhammad (n 16) 146. 
is an integral component of the requirement that an accused should have a fair trial'. ${ }^{31}$ However, for other scholars the fair trial rights consist of all the rights of the accused provided in Article 14 ICCPR, not limited to those prescribed in the Article 14 (1) ICCPR. ${ }^{32}$ Nevertheless, for the purpose of this work, the 'fair trial rights' will be treated as in the text of the ICCPR consisting of the following: equality of arms, publicity of proceedings, impartiality and independence of the judges. ${ }^{33}$

The principle of equality of arms provides that the parties (not only the accused) must be given equal rights during proceedings before tribunal. ${ }^{34}$ International criminal law follows the general understanding of this principle. ${ }^{35}$ One of its application is the obligation imposed on the prosecutor to disclose to the defence evidence collected during the preliminary investigation. The question remains whether the defence is also obliged to disclose to the prosecution materials collected prior to the trial. The ICTY case law is contradictory on that issue. ${ }^{36}$ It seems that more obligations in that matter should be imposed on the prosecution. The prosecutor of the ICTY possesses all instruments and powers that allow him to conduct a full-scale professional investigation involving such actions as the interrogation of witnesses. And even the prosecutor may have problems with access to certain information and witnesses due to the lack of cooperation of the state in which investigation takes place. Nonetheless defence lawyers do not enjoy the same treatment. Therefore, the results of the prosecutor's investigation should be revealed to them to mitigate the disproportion between the positions of the parties.

It should be also noticed that the ad hoc tribunals are slowly evolving from the common law system to the civil law, at least in the area of the role of the judge in the control of the proceedings. Since the establishment of the ad hoc tribunals the trial chambers have gained the right to acquaint themselves with materials from the preliminary investigation, which were not available to the judges previously. At the beginning the common law approach of a judge tabula rasa presiding over a trial, not knowing anything more than the name of the accused and the charges against him, was a typical sight in ICTY and ICTR. That system has been recognized as ineffective in the light of thousands of pieces of physical evidence and hundreds of witnesses processed during trials. Judges unfamiliar with the background of the case and claims to be proven by both sides had no possibility to take control over the trial proceedings in the way necessary

${ }^{31}$ Prosecutor v Furundzija (Lasva Valley) [2000] IT-95-17/1-A.

32 May and Wierda (n 27) 259, Christoph JM Safferling, Towards an International Criminal Procedure (OUP 2003) 24.

${ }^{33}$ See also on the notion of fair trial Paweł Wiliński, Hanna Kuczyńska, 'Rzetelny proces karny w orzecznictwie Międzynarodowego Trybunału Karnego' in Paweł Wiliński (ed) Rzetelny proces karny w orzecznictwie sądów polskich i międzynarodowych (Wolters Kluwer Polska 2009) 181231.

${ }^{34}$ See Płachta (n 2) 727-740.

${ }^{35}$ Article 20 (1) ICTR Statute and Article 21 (1) ICTY Statute

${ }^{36}$ See Tadić (Decision on Prosecution Motion for Production of Defence Witness Statements) IT-94-1-T (27 Novemeber 1996) and Delalić (Decision on the Prosecutor's Motion for an Order Requiring Advance Disclosure of Witnesses by the Defence Witness Statements) IT-96-21-T (4 February 1998). 
to provide the accused with equal chances. Presumably the introduced changes were to restrain the powers of the prosecution and balance parties' rights during proceedings before the ICTY and ICTR. Nonetheless, some authors are careful when assessing those innovations. Some question the impartiality of the judges after the changes, ${ }^{37}$ others argue that even the introduction of such instruments has not been satisfactory enough to achieve "equality of arms". ${ }^{38}$ In proceedings before the ICC one of the assurances that the discussed principle will be observed is Article 67 (1) (b) of the Rome Statute giving the accused the adequate time and facilities to prepare a defence, which refers to Article 14 (3) (b) of the ICCPR. Still, the meaning of 'adequate time and facilities' will be open to the ICC trial chambers' interpretations.

The second element of the fair trial in criminal proceedings, the principle of public hearing was aptly summed up by the ICTY Trial Chamber stating that '[o]ver and above the reasons that public proceedings facilitate public knowledge and understanding and may have a general deterrent effect, the public should have the opportunity to assess the fairness of the proceedings' ${ }^{39}$ It has to be admitted that even though this principle was not set out in the Charter of the IMT and the IMTFE, the war trials were easily accessible to public, ${ }^{40}$ yet it was not until the contemporary era of international criminal law when thorough provisions regarding public trials were provided. ${ }^{41}$ Indeed, the international tribunals have established new standards. Not only judgments, orders and decisions are available online but also full transcripts from the Chambers' sessions. ${ }^{42}$ Moreover, ICTY, ICTR and ICC make proceedings accessible to public through live online coverage from the courtrooms.

As all international criminal law instruments provide, ${ }^{43}$ the right of accused to a public trial may be limited by the need to protect witnesses and victims by e.g. conducting proceedings in camera and providing witnesses with a chance to remain anonymous to the accused. ${ }^{44}$ It must be noted that limitations of the right of the accused to a public trial due to the need to protect witness is quite controversial. From an Anglo-American perspective the right of the accused to examine the witness has to be closely connected with knowledge of

\footnotetext{
${ }^{37}$ Keen (n 19) 779. See also Safferling (n 32) 268.

${ }^{38}$ Salvatore Zappala, Human Rights in International Criminal Proceedings (OUP 2003) 112.

${ }^{39}$ See May and Wierda (n 27) 281, referring to the view expressed in the Prosecutor $v$ Kunarac et al. (Foca) (Order on Defense Motion Pursuant to Rule 79) IT-96-23\&23/1-T (22 March 2000). See also Płachta (n 2) 740-745.

${ }^{40}$ May and Wierda (n 27) 282.

${ }^{41}$ See Article 21 (2) ICTY Statute, Article 20 (2) ICTR Statute, Article. 67 (1) Rome Statute.

${ }^{42}$ See ICTR webpage: $<$ http://www.unictr.org $>$ and ICTY webpage: $<$ http://www.icty.org $>$ and ICC webpage: $<$ http://www.icc-cpi.int $>$

${ }^{43}$ See Article 22 ICTY Statute, Article 21 ICTR Statute, Article 68 Rome Statute.

${ }^{44}$ See more on the witness and victims protection in Helen Brady, 'Protective and Special Measures for Victims and Witnesses' in Roy S Lee (ed), The International Criminal Court. Elements of Crimes and Rules of Procedure and Evidence (Transnational Publishers 2001) and John RWD Jones, 'Protection of Victims and Witnesses' in Antonio Cassese, Paola Gaeta and John RWD Jones (eds) The Rome Statute of the International Criminal Court. A Commentary, vol. II (OUP 2002).
} 
his identity, as the defence can also attack the character of the witness, his previous behavior, etc. Hiding the identity of a witness using a nickname or shielding him from the accused so his face is not seen is, in the eyes of common law lawyers, an act depriving the accused of his basic right to confront the witness.

Another element of the fair trial is the right of the accused to be tried before a competent, independent and impartial tribunal established by law. ${ }^{45}$ Referring to Cassese, such a tribunal shall consist of only politically independent judges without any interest in the interests and concerns of the parties, and shall include mechanisms allowing biased judges to be removed from a case (or a court). ${ }^{46}$ The law of both ICTY and ICTR provides several mechanisms for appointing judges ${ }^{47}$, their disqualification ${ }^{48}$ as well as systems of privileges and immunities ${ }^{49}$ that, as expected, should protect them from any State influence. And once again, provisions of the ICC law are far more detailed. ${ }^{50}$ While the law of ad hoc tribunals does not provide any specific provisions on independence of judges, stating only that Chambers should be composed of independent judges, the Rome Statute in Article 40 not only assures that judges should be independent but also defines the meaning of that word. As provided in paragraphs 2 and 3 of the same article '[j] udges shall not engage in any activity which is likely to interfere with their judicial function or to affect confidence in their independence' and that permanent judges '[...] shall not engage in any other occupation of a professional nature'. It is worth pointing out that sometimes defence lawyers attempt to challenge the jurisdiction of the court, basing their arguments on a lack of independence of the court and judges due to the relationship between the United Nations, which established the ad hoc tribunals, and the ICTY and ICTR. ${ }^{51}$

\section{B. Presumption of innocence}

The principle that each person should be presumed innocent until guilt is proven is a cardinal principle of criminal proceedings and one of the most recognizable rights of the accused in the civilized world. ${ }^{52}$ It is expressed literally

\footnotetext{
${ }^{45}$ Article 14 (1) of the ICCPR. But see Article 6 of the ECHR and Article 8 of the AmCHR for modification of this right.

${ }^{46}$ Cassese (n 18) 393.

${ }^{47}$ Article 13 of the ICTY Statute and Article 12 of the ICTR Statute.

${ }^{48}$ Rule 15 of the ICTY RPE and Rule 15 of the ICTR RPE.

${ }^{49}$ Article 30 of the ICTY Statute and Article 29 of the ICTR Statute.

50 Article 36 of the Rome Statute regarding qualifications, nomination and election of judges, Article 40 of the Rome Statute on independence of judges and Article 41 of the Rome Statute referring to disqualification of judges broadened by Rule 34 of the ICC RPE.

${ }^{51}$ Kanyabashi (Decision on the Defence Motion on Jurisdiction) IT-96-15-T (18 June 1997). See also Tadić (Decision on the Defence Motion on Jurisdiction) IT-94-1-T (10 August 1995) para. 8.

52 Zappala, 'The Rights of Accused' in Cassese, Gaeta and Jones (n 44) 1340; Safferling (n 32) 256 and May and Wierda (n 27) 289.
} 
in both $\mathrm{UDHR}^{53}$ and $\mathrm{ICCPR}^{54}$ and in a number of other international treaties. ${ }^{55}$ The presumption of innocence is also recognized by national laws in various countries. $^{56}$

Therefore, it should not be surprising that rules governing international trials and courts contain relevant provisions. ${ }^{57}$ Article 21 (3) of the ICTY Statute and Article 20 (3) of the ICTR Statute provide that ' $[\mathrm{t}]$ he accused shall be presumed innocent until proven guilty according to the provisions of the present Statute'. More specific regulation can be found in Article 66 of the Rome Statute entitled 'Presumption of innocence' which provides as follows:

'Article 66 of the Rome Statute

1. Everyone shall be presumed innocent until proved guilty before the Court in accordance with the applicable law.

2. The onus is on the Prosecutor to prove the guilt of the accused.

3. In order to convict the accused, the Court must be convinced of the guilt of the accused beyond reasonable doubt'.

It is essential to discuss and explain the most important issues regarding this principle. Firstly, I will discuss the problem of application of the presumption of innocence in the proceedings. Although the main focus of the paper remains on the rights of the accused during the trial I believe that, for the purposes of clarification, it is necessary to provide an explanatory discussion regarding the application of this principle in the pre-trial investigation. Secondly, the rule imposing the burden of proof on the Prosecutor will be discussed. Finally, I will conclude with a discussion on the presumption of innocence in respect of coverage of the trial by media.

In literature a continuing discussion on the application of the presumption of innocence principle in pre-trial proceedings can be found. The international rules of law do not provide an exact moment when the protection of the accused should commence (see Article 11 (1) of the UDHR and Article 14 (2) of the ICCPR). The rules only set out the ending date which is the conviction of the accused. The same approach is also applied by the Statutes of ad hoc tribunals and the ICC. Moreover, the regulations of ICTY, ICTR and ICC differentiate

${ }^{53}$ Article 11 (1) of the UDHR provides that '[e]veryone charged with a penal offence has the right to be presumed innocent until proved guilty according to law in a public trial at which he has had all the guarantees necessary for his defence'.

${ }^{54}$ Article 14 (2) of the ICCPR provides that '[e]veryone charged with a criminal offence shall have the right to be presumed innocent until proved guilty according to law'.

${ }_{55}^{5}$ Article 6 (II) of the ECHR, Article 8 (II) of the AmCHR.

${ }^{56}$ The principle is recognized, among others, in Article $5 \S 1$ and Article 74 of the Kodeks Postępowania Karnego (Polish Code of Criminal Procedure), Dz. U. 1997 r. Nr 89, poz. 555 ze zm [k.p.k.], however it must be noted that some States have adopted the principle that the accused shall not be presumed guilty instead of presumed innocent. See Zappala, 'The Rights of Accused' (n 52) 1341.

${ }^{57}$ It has to be pointed out that 'the Nuremberg and Tokyo Charters did not explicitly recognize the presumption of innocence' as stated in Zappala, Human Rights in International Criminal Proceedings (n 38) 84. However, as Zappala further argues, the presumption of innocence 'was accepted de facto'. 
between the notion of accused and suspect ${ }^{58}$, and therefore it can be argued that a literal interpretation of those articles would lead to the conclusion that the 'accused' is presumed innocent only during the trial stage. It can be argued that if this principle were to also apply during the investigation and before the charges are confirmed, it would be provided for as such in the appropriate articles.

Nevertheless numerous authors agree that the presumption of innocence should be applicable to both the accused and a suspect until the moment guilt is proven, meaning during the pre-trial investigation and trial proceedings. ${ }^{59} \mathrm{~S}$. Zappala explains the issue clearly:

'First, it would be totally illogical for the judge reviewing the charges to presume that the suspect is guilty. Secondly, if the presumption of innocence were not applicable before the confirmation of charges, irreparable prejudice could be done to the rights of the individual prior to confirmation (for example, through a campaign depicting the suspect as a criminal or by the adoption of asset-freezing measures). Thus, any subsequent protection would prove ineffective' ${ }^{60}$

In my opinion the approach presented above protecting both a suspect and an accused is the only one that can be acceptable in the civilized world. Any other would deprive a potential accused of his right to be presumed innocent.

The Rome Statute resolves the problem explicitly. Article 66 (1) of the Rome Statute as quoted above clarifies that it is not only the accused who needs to be presumed innocent. The quoted article states that 'everyone' shall be treated in such a way, establishing that this is a right which should be attributed to every person. Therefore, it is clear that the rules of international criminal law go further than those of human rights law, encompassing the suspect with protection as well as each other person involved in the criminal proceedings.

Generally, the presumption of innocence principle allows for the inference that the burden of proof in criminal proceedings is imposed on the Prosecutor. ${ }^{61}$ As mentioned before, such regulation is not directly provided for in the UDHR and ICCPR or any other international convention. Furthermore, ICTY and ICTR Statutes do not include such a rule in their provisions. However, it cannot be said that the Statutes or the Rules of the ICTY and ICTR are in breach of the presumption of innocence for not having explicitly stated that onus probandi rests on the Prosecution. ${ }^{62}$ It seems that this can be derived from the law of ad hoc tribunals by judges. The question remains whether this should be

\footnotetext{
${ }^{58}$ See chapter I. point $C$.

${ }^{59}$ Safferling (n 32) 67, Zappala, Human Rights in International Criminal Proceedings (n 38) 84, Cassese (n 18) 390 and Calvo-Goller (n 21) 56.

${ }^{60}$ Zappala, Human Rights in International Criminal Proceedings (n 38) 85.

61 Zappala, 'The Rights of Accused' (n 52) 1344. In literature there can be found an argument that in the Continental system the presumption of innocence does not mean that the onus probandi lies on the Prosecutor, but due to the civil law court's obligation to establish the truth it is rather imposed on the judge (see Muhammad (n 16) 150). However such an argument referring to all civil law countries should be considered as too general since at least the Polish Code of Criminal Procedure provides directly that the burden of proof lies in Prosecutors' hands. See for further explanation on the Continental system regarding the burden of proof using Germany as an example Safferling (n 32) 257 and generally Delmas-Marty and Spencer (n 19).

62 Zappala, Human Rights in International Criminal Proceedings (n 38) 91.
} 
left for such interpretation rather than be provided explicitly in the law of ad hoc tribunals.

The case law of ad hoc tribunals confirms this approach. In Brdjanin the ICTY Trial Chamber argued that the presumption of innocence '...places on the Prosecution the burden of establishing the guilt of the Accused [...]. That burden remains on the Prosecution throughout the entire trial; it never changes' ${ }^{63}$ However, it must be pointed out that there is one situation in which the burden of proof shifts to the defence. As it was argued by the Appeal Chamber in Delalic et al., the accused is responsible for proving his insanity in a case when he uses such an argument in his own defence seeking acquittal. ${ }^{64} \mathrm{It}$ is clear that this is the sole exception to the strict rule of imposing the burden of proof on the Prosecution and applies only to insanity pleas.

The ICC once again clarifies the concern as it is stated clearly in the Rome Statute that the burden of proof lies in the Prosecutor's hands ${ }^{65}$ and that accused has a right 'not to have imposed on him or her any reversal of the burden of proof or any onus of rebuttal' ${ }^{66}$ Without any doubt this provides successful clarification of the discussed issue and protects the accused directly with greater effect than provisions of the ad hoc tribunals and human rights law.

Despite that the obligation to provide the accused with protection is directed to the court, the role of media during international criminal trials can be in contradiction with the presumption of innocence. It is not uncommon that television, radio and press deliver a verdict before the judgment has been deliberated in a court of law. This also takes place on the national level, however, the international criminal law environment is particularly prone to such behaviours. The gravity of offences in this field of law and awareness of what happened in Rwanda and Yugoslavia brings attention to the trials held before international courts. The media tend to present the ongoing cases in an extremely biased way, portraying those accused of crimes against humanity, war crimes and genocide already as guilty criminals and monsters. ${ }^{67}$ No remedy against such an approach is designed for international criminal proceedings; it needs to be introduced in the near future to assure the accused a fair trial. ${ }^{68}$

\section{Right to be informed of the charges against the accused}

Article 14 (3) (a) of the ICCPR provides that everyone shall be entitled 'to be informed promptly and in detail in a language which he understands of the nature and cause of the charge against him'. Obviously, detailed information about the nature and cause of the charge is required if the accused is to prepare himself properly for his or her defence.

${ }^{63}$ Prosecutor v Brdjanin (Krajina) (Judgment) IT-99-36-T (1 September 2004) 22.

${ }^{64}$ Prosecutor v Delalić et al. (Celebici) [1998] IT-96-21-T 1157.

${ }^{65}$ Article 66 (2) of the Rome Statute.

${ }^{66}$ Article 67 (1) (i) of the Rome Statute.

${ }^{67}$ Cassese (n 18) 390.

${ }^{68} \mathrm{ibid} 391$. The author points out that in national laws 'the accused is offered the right to sue the media for libel'. If such a remedy was to be introduced into international criminal proceedings, the question of what court would have jurisdiction over that suit should be addressed. 
Under the law of ad hoc tribunals this right is repeated almost literally (only some changes regarding a gender-neutral form are made) in Article 21 of the ICTY Statute and Article 20 of the ICTR Statute. Furthermore, the Rules of Procedure and Evidence provide detailed rules regarding the conduct of disclosure of not only the charges but also the evidence for the case.

The Rome Statute in Article 67 (1) (a) broadens the scope of protection, stating that the accused should be entitled 'to be informed promptly and in detail of the nature, cause and content of the charge, in a language which the accused fully understands and speaks [emphasis added]'. Furthermore, Article 61 (3) referring to the hearing to confirm the charges on which the Prosecutor intends to seek trial, demands an even higher standard of information. ${ }^{69}$

The ICC regulations are wider and more comprehensive than the law of the ad hoc tribunals and human rights law. As with other rights of the accused, the ICC places a lot of attention to his understanding of the charges and proceedings. Therefore, I believe that especially in this area the protection of the accused has been enormously expanded within international criminal law. Obviously, the regulations provided in the law of the ICC result from the experience of trials held before the ICTY and ICTR.

\section{of a defence \\ D. Right to an expeditious trial and to have time for the preparation}

Another important right of the accused is the right to an expeditious trial (to be tried without 'undue delay' or 'within a reasonable time'). ${ }^{70}$ This right is aimed to ensure the quickest possible determination of the charges imposed on the accused and undoubtedly applies to all stages of criminal proceedings, commencing with the investigation and concluding with appellate procedure. As was mentioned before, the ICCPR incorporates this right in Article 14 (3). ${ }^{71}$ It is also expressed literally in the provisions of Article 21 (4) (c) of the ICTY Statute, Article 21 (4) (c) of the ICTR Statute and Article 67 (1) (c) of the Rome Statute. The law requires that officials in charge of the proceedings should observe the right to an expeditious trial, at the same time ensuring for the accused the right to have adequate time for the preparation of his defence. ${ }^{72}$ Not always does the rapid issuance of a judgment lie in the interests of the accused, who may try to prolong the proceedings as long as possible. Therefore, scholars argue that the right to an expeditious trial is in fact not the right of the accused, but more likely is 'a norm that imposes a duty on the Trial Chamber in the public interest'. ${ }^{73} \mathrm{On}$

\footnotetext{
${ }^{69}$ Within a reasonable time before the hearing, the person shall: (a) be provided with a copy of the document containing the charges on which the Prosecutor intends to bring the person to trial; and (b) be informed of the evidence on which the Prosecutor intends to rely at the hearing. The Pre-Trial Chamber may issue orders regarding the disclosure of information for the purpose of the hearing.

${ }^{70}$ It is worth noticing that some authors consider rights 'to an expeditious trial' and 'to be tried without undue delay’ as separate rights. See for example May and Wierda (n 27) 278.

${ }^{71}$ See also Article 6 (1) of the ECHR and Article 8 (1) of the AmCHR.

72 This right can also be found in both human rights law (art. 14 (3) (b) of the ICCPR) and international criminal law (Article 21 (4) (b) of the ICTY Statute, Article 20 (4) (b) of the ICTR Statute, Article 67 (1) (b) of the Rome Statute).

73 Zappala, 'The Rights of Accused' (n 52) 1339.
} 
the other hand, international criminal trials are usually very complex and timeconsuming. Normally they require deep cooperation between States, and the sometimes difficult collection of necessary evidence along with questioning of a great number of witnesses. Hence, even though the provisions of the legal regulations cited above require observance of the right to a speedy trial, it may be that the execution of that right that is in contrary with the human rights law.

\section{E. Prohibition of trial in absentia}

Trials in absentia, i.e. trials held without the presence of the accused, are forbidden in the Anglo-American law system, while under some circumstances they are allowed under the continental regime. ${ }^{74}$ The ICCPR seems to leave no doubt regarding this issue providing in Article 14 (3) (d) in principio that the accused has a right 'to be tried in his presence'. ${ }^{75}$ However, in the opinion of some scholars, this provision of international human rights law does not mean that the trials in absentia are prohibited. ${ }^{76}$ Others understand this regulation differently. For example, in the Report of the Secretary-General of the UN an opposing interpretation can be found which states:

'A trial should not commence until the accused is physically present before the International Tribunal. There is a widespread perception that trials in absentia should not be provided for in the statute as this would not be consistent with article 14 of the International Covenant on Civil and Political Rights, which provides that the accused shall be entitled to be tried in his presence'. ${ }^{77}$

The law of the ad hoc tribunals forbids trial in absentia by means of Article 21 (4) (d) of the ICTY Statute and Article 22 (4) (d) of the ICTR Statute. Nevertheless, Rule 61, common to RPE of both tribunals, provides specific procedures in the case of failure to execute a warrant of arrest that functions as a trial in absentia. Rule 61 is criticized by some authors for not offering effective protection of the accused. ${ }^{78}$ The rule is considered by others as not introducing trials in absentia into international criminal law, since guilt is not established on that level of proceedings. ${ }^{79}$ Moreover, the practice of ad hoc tribunals proves that the trial in its full sense cannot start without the accused being present in the courtroom. Good examples of that are the cases of Ratko Mladić and Radovan Karadzić. The trials against those two accused did not commence until they were arrested, transferred to the ICTY and made available for trial. The procedure

\footnotetext{
${ }^{74}$ See Mario Chiavario, 'Private parties: the rights of the defendant and the victim' in DelmasMarty and Spencer (n 19) 571.

${ }^{75}$ ECHR contains similar provisions in Article (6) (1).

${ }^{76}$ Cassese (n 18) 402.

${ }^{77}$ Report of the Secretary-General Pursuant to paragraph 2 of Security Council Resolution 808 (1993), S/25704, 101.

${ }^{78}$ Alphons Orie, 'Accusatorial v Inquisitorial Approach in International Criminal Proceedings' in Cassese, Gaeta and Jones (n 44) 1467.

${ }^{79}$ Prosecutor v Rajić (Stupni Do) (Review of the Indictment Pursuant to Rule 61 of the Rules of Procedure and Evidence) IT-95-12 (13 September 1996) 2-3 under B Preliminary Matters.
} 
prescribed in Rule 61 provides only for the establishment of whether there are reasonable grounds for believing that the accused committed the crimes of which he is charged in the indictment.

It seems that the ICC does not resolve the uncertainty in this area and the same doubts can be raised with regard to the provisions of the law of ICTY and ICTR. Article 63 (1) of the Rome Statute provides clearly that 'the accused shall be present during the trial'. However, the following paragraph regulating the situation in which the accused continues to disrupt the trial and therefore may be temporarily removed from the courtroom does not affect this regulation. As Article 63 (2) states, 'such measures shall be taken only in exceptional circumstances after other reasonable alternatives have proved inadequate, and only for such duration as is strictly required'. The accused will have the right to communicate with his counsel from outside the courtroom. It should be noted that removal may occur only after the accused has appeared in the courtroom and then disrupts the proceedings. Therefore, commencing the trial without the presence of the accused is impossible. On the other hand, a similar procedure to that of Rule $61 \mathrm{RPE}$ ICTY/R is available in the law of the ICC.

\section{F. Right to counsel}

The accused in criminal law is granted with the right to defend himself alone or with the help of counsel. ${ }^{80}$ The protection of that right is assured in the ICCPR $^{81}$ and other international human rights treaties, ${ }^{82}$ as well as in the national laws of many States. ${ }^{83}$ This right has been designed to protect the accused from harm that may be done to him by 'inhumane' legal mechanisms. Typically the accused is not a lawyer, nor familiar with criminal proceedings, and is usually unable to cope with the complicated rules of national laws. Therefore, it is not uncommon that the accused is effortlessly intimidated by regulations regarding his rights and obligations.

The laws of international criminal courts and tribunals are even more problematic. This field of law is considered as one of the most incomprehensible, providing unique solutions. This is due to the fact that the laws of international criminal tribunals and courts were created by taking specific rules from common and civil law systems, melting them together for the sake of assuring fair and expeditious international criminal trials. Moreover, the gravity of offences of which the person is accused brings enormous public attention and, with the

${ }^{80}$ See Paweł Wiliński, 'Prawo do obrony w postępowaniu przed Międzynarodowym Trybunałem Karnym' (2005) 1 RPEiS 109.

${ }^{81}$ The provisions of Article 14 (3) (d) of the ICCPR provide that the accused has a right "to defend himself in person or through legal assistance of his own choosing; to be informed, if he does not have legal assistance, of this right; and to have legal assistance assigned to him, in any case where the interests of justice so require, and without payment by him in any such case if he does not have sufficient means to pay for it". Furthermore he must be granted with 'adequate time and facilities for the preparation of his defence and to communicate with counsel of his own choosing' (Article 14 (3) (b) of the ICCPR).

${ }^{82}$ See for example Article 6 (III) (c) of the ECHR.

${ }^{83}$ This right can be found in both civil law legal systems, for example Article 6 and Article 7781 of the Polish Code of Criminal Procedure and in common law ones, for example in the Sixth Amendment to the US Constitution. 
media's help, creates an atmosphere in which the accused is presumed to be guilty. Therefore, the accused in international criminal trials usually demand legal assistance. ${ }^{84}$

The most crucial issue with regard to this right, both in human rights law and international criminal law, is if the accused has a right to the counsel of his own choice even in a situation when, in the words of the ICCPR, 'he does not have sufficient means to pay for it'. As Kay and Swart argue, '[a]lthough such an absolute right has not been recognized, it seems to be generally accepted that regard should be had to the wishes and preferences of the defendant unless there are relevant and sufficient reasons making it necessary to override them' ${ }^{85}$ Is this general acceptance valid only in the human rights law framework or is it adopted in the law of the international criminal courts and tribunals as well?

The law of the historical tribunals provided the accused with the assistance of counsel. ${ }^{86}$ ICTY and ICTR also provide such disposition in Article 21 (4) (d) of the ICTY Statute and Article 20 (4) (d) of the ICTR Statute, repeating directly the provisions of Article 14 (3) (d) of the ICCPR. It is worth pointing out that ICCPR regulations refer to 'everyone' in the situation when the criminal charges against such a person are established. International criminal tribunals decided to create separate provisions for the accused (as presented above) and for a suspect (Article 18 (3) of the ICTY Statute and Article 17 (3) of the ICTR Statute). Interestingly, the right to a counsel for the latter is limited to the situation when the suspect is "questioned." Nevertheless, it seems unreasonable to limit the protection of a suspect only to such circumstances as interrogation. If the accused is to be granted a fair trial he should also be given full protection during the initial stages of proceedings when he is a suspect. Some further modifications regarding this issue should be introduced in the future. The Rome Statute does not help in this matter. Article 55, containing general provisions on rights of persons during investigations, refers to the right to counsel in section (2) (c). Obviously, the authors of the Rome Statute paid more attention when drawing up the law to the situation of the suspect than of the accused.

It seems that the qualifications of lawyers taking the responsibility to act as defence counsels in international criminal proceedings are of serious importance. Nevertheless, neither human rights law nor the historical tribunals have resolved the question of the level of education and experience a lawyer ought to possess in order to practice before courts and tribunals. International criminal trials are the ones that should be regarded with particular attention. The cases investigated and tried before the international tribunals and courts are, as was pointed out above, complex and involve great amounts of time, hundreds of witness and very complicated issues to be resolved. Therefore, clarification regarding who can represent the accused in such a trial becomes necessary.

\footnotetext{
${ }^{84}$ One of the most interesting cases referring to this problem is the Milosevic case, where the accused Slobodan Milosevic did not recognize the jurisdiction of the ICTY and refused to appoint a lawyer at the same time refusing to defend himself in person.

${ }^{85}$ Steven Kay and Bert Swart, 'The Role of the Defence' in Cassese, Gaeta and Jones (n 44) 1430 .

${ }^{86}$ Article 16 (d) IMT Charter and Article 9 (c) IMTFE Charter.
} 
The ICTY and ICTR decided to address this issue in Rules 44-46 of both RPE as well as in the Directive on the Assignment of Defence Counsel.${ }^{87}$ Counsel should be considered as qualified if he or she is admitted to the practice of law in a State, or is a University professor of law (Rule 44 (A)), speaks one or both working languages of the Tribunal (Rule 44bis (A)), has at least 10 years' relevant experience and has indicated willingness to be assigned by the tribunal (Rule 45).

The creators of the Rome Statute decided that this set of qualifications is insufficient for the protection of the accused. Rule 22 (1) of the ICC RPE provides that:

A counsel for the defence shall have established competence in international or criminal law and procedure, as well as the necessary relevant experience, whether as judge, prosecutor, advocate or in other similar capacity, in criminal proceedings. A counsel for the defence shall have an excellent knowledge of and be fluent in at least one of the working languages of the Court. Counsel for the defence may be assisted by other persons, including professors of law, with relevant expertise.

The cited rule should be assessed positively. International criminal trials are not only complicated but also demand the deepest knowledge of criminal procedure and international law. It seems that merely being admitted to practice or having 10 years of employment at a university (as ICTY and ICTR provide) is not enough. In my opinion, perhaps some further education in both common and civil law systems should be added as another requirement, since international criminal procedure is unlike any other in the world in combining those two. Moreover, so many controversial issues arise from the combination of civil and common law systems that, as I believe, only those who possess at least a general understanding of both systems are able to provide the accused with effective support and representation.

International criminal law has developed rules protecting the accused in terms of his right to counsel in a more comprehensive and detailed way than human rights law provides. The law of the ICTY, ICTR and ICC not only explicitly state that a suspect should also be protected by having a representative, but also developed the standards of qualification for practice. It is expected that the practice of international criminal courts and tribunals will help in preparing a complete set of qualifications for counsel.

\section{H. Right to examine or have examined witnesses}

Under the ICCPR the accused has a right 'to examine, or have examined, the witnesses against him and to obtain the attendance and examination of witnesses on his behalf under the same conditions as witnesses against him' (Article $14(3)(\mathrm{e})$ ). This is one of the areas where civil and common law system

87 Directive on the Assignment of Defence Counsel, Registrar of the International Criminal Tribunal for Rwanda (9 January 1996) and Directive on the Assignment of Defence Counsel, IT/73/REV.10, Registrar of the International Criminal Tribunal for the Former Yugoslavia (28 July 1994). 
differ the most with regard to criminal procedure. While in the Anglo-American system cross-examination is a typical feature of a criminal trial always undertaken by the parties, in the continental system, at least in practice, it is the judge who is responsible for calling and questioning witnesses. Therefore, parties in the civil law system do not always feel that it is necessary to intervene since the responsibility of discovering the truth during the trial has been entrusted to the judge. Nevertheless, the rule allowing for questioning of any witness is laid out in the same manner in the law of both systems and if the parties feel such a need they can apply it in criminal proceedings. ${ }^{88}$

International human rights law is unambiguous when it comes to the consequences of the accused being unable to cross-examine witnesses testifying against him. However, on several occasions the European Court of Human Rights has decided that such evidence cannot be the sole basis for conviction of the accused. ${ }^{89}$

Provisions on the right to examine the witness were adopted in the historical trials. ${ }^{90}$ In the law of the ad hoc tribunals this right is provided not only in their Statutes, which adopt the general rule ${ }^{91}$, but has been expanded further in the RPE of both tribunals. Common Rule 85 (A) entitles each party 'to call witnesses and present evidence'. The following Rule states that 'examination in chief, cross-examination and re-examination shall be allowed in each case' providing that 'a Judge may at any stage put any question to the witness'. The law of the ICC repeats the provisions of ICCPR also almost literally. ${ }^{92}$

It seems obvious that the protection provided in human rights law regarding the accused right to question a witness in a manner prescribed as crossexamination is observed by the law of the international criminal courts and tribunals. The ICTY and ICTR conduct their trials in the adversarial manner. However, even though a movement towards the civil law system in the ICC can be observed, it is clear that with the provisions of Article 67 (1) (e) of the Rome Statute, the right of the accused for cross-examination will be respected. It can be already observed in the current proceedings before the ICC. Nevertheless, the lack of an explicit provision cannot be assessed positively and leaves space for wide discretion of the trial chamber. That said, it should be noted that the issues of the anonymity of the witness and the accused's right to cross-examine him in person or via video-link can arise, as well as the question of the admissibility of hearsay evidence. It is true that international courts and tribunals struggle with

${ }^{88}$ See generally on witness examination in the civil and common law system Denis Salas, 'The role of the judge' in Delmas-Marty and Spencer (n 19) 488.

${ }^{89}$ See Kostovski $v$ The Netherlands (20 November 1989) Series A no 166 and Unterpertinger $v$ Austria (24 November 1986) Series A no 110.

${ }^{90}$ See Article 16 (e) of the IMT Charter and Article 9 (d) of the IMTFE Charter.

${ }^{91}$ Article 20 (4) (d) of the ICTY Statute and Article 21 (4) (d) of the ICTR Statute repeat literally the ICCPR provisions.

${ }^{92}$ Article 67 (1) (e) of the Rome Statute. 
assuring balance between the rights of the accused and protection of victims and witnesses. $^{93}$

\section{Right to an interpreter}

The next right of the accused is the right to an interpreter; in the words of Article 14 (3) (f) of the ICCPR 'to have the free assistance of an interpreter if he [the accused] cannot understand or speak the language used in court'. This right ensures that the accused who is not familiar with any of the official languages of a tribunal will be able to understand the proceedings and properly defend himself. The reader should be aware that this right, which seems to be of little importance, involves the more general problem of languages. ${ }^{94}$ This right is considered as crucial as the requirement to be informed of the charges. ${ }^{95}$

In this case as well the ICC provides a higher standard with its provisions regarding the right to an interpreter, stating that the accused should have the right:

'To have, free of any costs, the assistance of a competent interpreter and such translations as are necessary to meet requirements of fairness, if any of the proceedings of or documents presented to the Court are not in a language which the accused fully understands and speaks' ${ }^{96}$

The ICTR and ICTY are far less comprehensive, providing only that both the accused ${ }^{97}$ and the suspect ${ }^{98}$ shall have the right to the free assistance of an interpreter, repeating the ICCPR provisions. Customarily in proceedings before ad hoc tribunals the accused is provided with extensive help, including translation of documents of the case. Nevertheless, basing the right of the accused on custom instead of on the letter of law does not protect him in an effective manner.

\section{J. Right to remain silent}

The right to remain silent (nemo tenetur se ipsum prodere), sometimes referred to as the privilege against self-incrimination, is looked upon differently in various traditions of criminal law. ${ }^{99}$ It is most likely derived from the common

\footnotetext{
${ }^{93}$ For further discussion on the issues mentioned see Zappala, Human Rights in International Criminal Proceedings (n 38) 129-140 and May and Wierda (n 27) 284-288.

94 Zappala, Human Rights in International Criminal Proceedings (n 38) 56-59. The author discusses several issues regarding language such as 1 . the problem of the determination of the language of translation and the standards for such determination; 2 . the problem of the relationship between working languages and the language of the suspect and his defence lawyer; 3. and the question whether the accused has a right to receive all documents from the Prosecution in a language he or she understands. Finally the author points out the importance of proper translation, since the language of law is different from the language in which people normally communicate. Perhaps the ICC resolutions in this matter will protect the accused sufficiently.

${ }^{95}$ Calvo-Goller (n 21) 168.

${ }^{96}$ Article 67 (1) (f) of the Rome Statute.

${ }^{97}$ Article 20 (4) (f) of the ICTR Statute and Article 21 (4) (f) of the ICTY Statute.

${ }^{98}$ Rule 42 (A) (ii) of the ICTR RPE and Rule 42 (A) (ii) of the ICTY RPE.

99 For further explanation regarding this issue see Zappala, Human Rights in International Criminal Proceedings (n 38) 77 and generally Delmas-Marty and Spencer (n 19).
} 
law tradition ${ }^{100}$ and even though it does not appear explicitly in the text of the $\mathrm{ECHR}^{101}$ it is present in the modern codes of criminal procedure throughout continental Europe. ${ }^{102}$ In the words of Article 14 (3) $(\mathrm{g})$ of the ICCPR the accused has the right "not to be compelled to testify against himself or to confess guilt". This protection, however, relates only to the accused and does not involve either a suspect nor a witness.

In a great number of detailed provisions the ad hoc tribunals grant both the suspect and the accused protection against self-incrimination. Article 21 (4) (g) of the ICTY Statute and Article 20 (4) (g) of the ICTR Statute broaden the scope presented in the ICCPR by providing that the accused has the right "not to be compelled to testify or to confess guilt and to remain silent, without such silence being a consideration in the determination of guilt and innocence'. Procedural rules expand the protection further. ${ }^{103}$ As the ICTY Trial Chamber noticed, no negative inference may be drawn from the silence of the accused, declaring:

'It is the right of the accused not to give evidence at trial and no adverse inference can be drawn from the fact he did not testify. The Trial Chamber refers to Article 21 (3) that guarantees the right to presumption of evidence and Article 21 (4) (g) which provides that the accused cannot be compelled to testify against himself' ${ }^{104}$

This approach remains in compliance with the understanding of what the right to remain silent means in civilized systems of law.

The ICC refers to the right to remain silent differentiating between the rights of persons during an investigation (Article 55 (1) (a) of the Rome Statute) and the rights of the accused. In the latter, the ICC derives this right from the presumption of innocence and the fact that the burden of proof lies on the Prosecutor in accordance with this principle. ${ }^{105}$ Therefore, the Rome Statute provides not only that the accused has a right "not to be compelled to testify or to confess guilt and to remain silent, without such silence being a consideration in the determination of guilt or innocence' (Article 67 (1) (i)) but also 'not to have imposed on him or her any reversal of the burden of proof or any onus of rebuttal' (Article 67 (1) (i)).

An examination of the approach to the privilege against selfincrimination in human rights law and international criminal law permits the

\footnotetext{
${ }^{100}$ Muhammad (n 16) 154.

${ }^{101}$ But see for example Murray v UK (1996) 22 EHRR 29 para. 45 (ECtHR 1973) in which the Court argued that 'the right to remain silent under police questioning and the privilege against self-incrimination are generally recognized international standards which lie at the heart of the notion of fair procedure under Article 6'.

${ }^{102}$ See e.g. Article $175 \S 1$ k.p.k. For continental lawyers this rule means that the accused (or suspect) can say anything, including lies, during any stage of proceedings, while in the common law system when the accused takes the stand

${ }^{103}$ See Rule 42 (A) (iii), Rule 55, Rule 63 and Rule 90 (E) identical for ICTY RPE and ICTR RPE.

${ }^{104}$ Prosecutor v Kupreskić et al. (Judgment) IT-95-16-T [2000] 339 (d).

105 Zappala, Human Rights in International Criminal Proceedings (n 38) 90.
} 
observation that the protection of the accused with regard to this issue seems more comprehensive in the latter system. The international criminal courts and tribunals not only acknowledge that the accused has a right to remain silent, but also enhance this protection by providing that no negative consequences for the accused (as well as for the suspect, and in the case of the ICC all persons during an investigation) can result from such behavior. Even though this precept exists within human rights law as a customary international law, its clarification should be evaluated more than positively. Additionally, explicit rules in the law of the ICC regarding the burden of proof improve protection of the accused tremendously.

\section{CONCLUSiOns}

The presented paper discusses the influence of international human rights law on international criminal law. The point at issue was whether the law of international courts and tribunals provides the same protection as can be seen in international human rights law, or rather further enhancements. After an in-depth examination of the rights of the accused in both branches of international law it can be stated with certainty that human rights law influenced the way in which the rights of accused are regulated in the law of the international criminal courts and tribunals.

The ICCPR provides the minimum standards for protection of the accused in criminal proceedings around the world, on both the national and international levels. For the most part the ad hoc tribunals repeat those provisions, in some cases expanding the protection. Good examples are the more detailed regulations regarding the right to counsel or the presumption of innocence. In some cases the judicial decisions of Trial and Appeals Chambers of the ICTY and ICTR have pushed the scope of protection even further, for example by acknowledging that no negative consequences for the accused can be derived from his decision to remain silent throughout criminal proceedings.

The improvement is even more visible when it comes to the law of the ICC. Almost every right of the accused is better developed and more comprehensive. It is also important to note that, through very detailed provisions, the certainty of the law has increased. It may be thought that the rights of accused prescribed more than 50 years ago are clearly identifiable. After a closer look into scholars' comments on what, for example, the right to a fair trial consists of, no one can deny the serious need for clarification. In the words of S. Zappala, it appears that the more the system is getting structured the more articulated the guarantees are'. ${ }^{106}$

Nevertheless, it has to be noted that proper protection of the accused cannot exist without precise provisions describing when a person becomes an accused. It seems that the ad hoc tribunals, in defining the exact moment of the conversion from suspect to accused as the filing of the indictment at court, did a much better job than the ICC with its blurry provisions on the issue in question.

${ }^{106}$ Zappala, 'The Rights of Accused' (n 52) 1353. 
It can be read out from the law of the ICC that the protection designed for the accused starts even earlier than in the law of the ad hoc tribunals, meaning after the confirmation of charges. However, since the exact moment is not provided as precisely as in the law of the ICTY and ICTR, a person can never be sure if the rights are already covering him. It could also open up the possibility for the prosecutor to decide when protection over the individual will commence. Therefore, even though the protection of the accused has increased in the law of international courts and tribunals some shortcomings are still visible. It is expected that in the practice of the courts, especially ICC, the trend towards broadening such protection will be maintained. 